\title{
Muhasebe Bilgilerinin Kalitesini Ölçmeye Yönelik Bir Çalışma: Borsa İstanbul Örneği ${ }^{*}$
}

\author{
Mahmut KARĞIN** \\ Nuray DEMIREL ARICI ${ }^{* * *}$
}

\section{ÖZET}

Muhasebe bilgilerinin kalitesi, birçok boyutu içerisinde barındıran geniş bir kavramdır. $\mathrm{Bu}$ nedenle muhasebe literatürü incelendiğinde, muhasebe kalitesi ile ilgili genel kabul görmüsş tek bir tanımın olmadiğl görülmektedir. Bununla birlikte, muhasebe standartlarını hazırlayan otoritelerin (FASB ve IASB) konuya yaklaşımı, muhasebe bilgilerinin kullanıclara karar verme aşamasında faydalı olması esasına dayanmaktadır. Bu çalışmanın amacı, sermaye piyasalarında raporlanan muhasebe bilgilerinin kalitesinin ölçülmesidir. Bu çalışmada, önceki çalışmalardan farklı olarak muhasebe kalitesinin ölçümünde çok boyutlu bir yaklaşım sergilenmiştir. Elde edilen bulgular neticesinde, çalışma dönemi, gözlem kümesi ve ele alınan kalite boyutları bağlamında Borsa İstanbul'da raporlanan muhasebe bilgilerinin genel olarak kaliteli olduğu sonucuna varılmıştır.

Anahtar Kelimeler: Muhasebe Bilgilerinin Kalitesi, Değer İlişkisi, Karların Sürekliliği, Nakit Akışlarının Tahmini, Borsa İstanbul.

JEL Sinıflandırması: M41, G12, C53.

\section{A Study on Measuring Accounting Quality: The Case of Borsa Istanbul ABSTRACT}

Accounting quality is a broad concept that contains various dimensions. So when the accounting literature is reviewed, it's seen that there is no unique and generally accepted definition of accounting quality. However, accounting standards regulatory authorities (FASB and IASB) deal with the concept based on providing useful information to users in their decision making process.

The purpose of this study is to measure the quality of accounting information reported in capital markets. In this study, a multidimensional approach is followed unlike the previous studies. When the findings are evaluated as a whole, it is concluded that the accounting information reported in Borsa Istanbul (BIST) is well-qualified in the context of the period, sample, and quality dimensions used in this study.

Keywords: Accounting Quality, Value Relevance, Earnings Persistence, Predicting Cash Flows, Borsa Istanbul.

Jel Classification: M41, G12, C53.

\footnotetext{
* Bu çalışma, Nuray DEMİREL ARICI'nın Celal Bayar Üniversitesi Sosyal Bilimler Enstitüsü İşletme ABD'nda

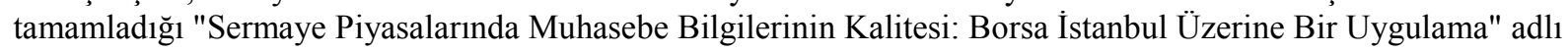
doktora tez çalışmasından türetilmiştir. Çalışmaya katkılarından dolayı Doç. Dr. Hüseyin AKTAŞ'a teşekkürlerimizi sunarız.

** Doç.Dr. Mahmut Karğın, Celal Bayar Üniversitesi, İktisadi ve İdari Bilimler Fakültesi, m_kargin@yahoo.com *** Arş.Gör. Dr., Nuray Demirel Arıcı, Celal Bayar Üniversitesi, Uygulamalı Bilimler Yüksekokulu, nuray.demirel@cbu.edu.tr
} 


\section{GİRIŞ}

Küreselleşme sürecinin 1980'li yıllardan sonra hız kazanmasıyla birlikte, ekonomiden siyasete, eğitimden bilgi ve iletişim teknolojilerine kadar her alanda yaşanan değişimler, "bilgi"nin önemini arttırmaktadır. İşletmelerin böyle bir ortamda faaliyetlerine devam edebilmeleri ve rekabet üstünlüğü sağlayabilmeleri, bilgiyi doğru yönetebilmeleriyle mümkündür. İşletmelerin bilgi sistemlerinden biri olan muhasebe bilgi sistemi, hem yöneticilerin hem de işletmeyle ilgili tarafların, karar verirken ihtiyaç duydukları bilgileri üretmesi açısından oldukça önemlidir.

Tüm bilgi sistemlerinde olduğu gibi, muhasebe bilgi sisteminin amacı, kullanıc1lara karar verme sürecinde yardımcı olacak kaliteli bilgilerin sağlanmasıdır. Geniş bir kullanıcı kitlesine sahip muhasebe bilgileri, kullanıcıların karar verme sürecini doğrudan etkilemektedir. Bu nedenle uluslararası arenada, muhasebe bilgilerinin kalitesinin arttırılması amacıyla uluslararası finansal raporlama standartları yayımlanmakta ve birçok ülke tarafindan kabul edilerek kullanılmaktadır. Bununla birlikte 2000'li yılların başında ABD'de (Enron, Worldcom) ve Avrupa'da (Ahold, Parmalat) yaşanan muhasebe skandalları, halka açık firmaların finansal raporlarına duyulan güveni sarsmış ve muhasebe bilgilerinin kalitesi sorgulanır hale gelmiştir.

$\mathrm{Bu}$ çalışmanın amacı, sermaye piyasalarında kullanılan muhasebe bilgilerinin kalitesinin ölçülmesidir. $\mathrm{Bu}$ çalışmada, önceki çalışmalardan farklı olarak, muhasebe kalitesinin ölçümünde çok boyutlu bir yaklaşım sergilenmiştir. Çalışmanın bundan sonraki kısmında, muhasebe bilgilerinin kalitesi hakkında genel bir çerçeve oluşturularak, kaliteli bilginin niteliksel özellikleri kısaca açıklanmış; sermaye piyasalarında bilginin önemi ve asimetrik bilginin piyasalarda yarattığı problemler vurgulanmıştır. Sermaye piyasalarında muhasebe bilgilerinin kalitesinin ölçümünde kullanılan yaklaşımlar teorik olarak incelenerek, söz konusu yaklaşımlara ilişkin yurtdışında ve ülkemizde yapılan ampirik çalışmalardan örnekler sunulmuştur. Son olarak, Borsa İstanbul'da muhasebe bilgilerinin kalitesini ölçmeye yönelik çok boyutlu bir uygulama gerçekleştirilmiştir.

\section{MUHASEBE BILGILERININ KALITESİ}

Muhasebe bilgilerinin kalitesi, çok boyutlu geniş bir kavramdır. Yapılan ampirik çalışmalarda muhasebe bilgilerinin kalitesi, farklı boyutlarıyla ele alınarak değerlendirilmektedir. Bu nedenle ilgili literatür incelendiğinde, muhasebe kalitesine ilişkin ortak bir tanımın yer almadığı görülmektedir. Gençoğlu ve Ertan (2012: 2) da literatürde kesin, açık ve genel kabul görmüş bir tanımın bulunmadığını ifade etmektedir. Bununla birlikte söz konusu kavram, finansal raporlamanın amacından yola çıkılarak tanımlanabilir.

Gerek Finansal Muhasebe Standartları Kurulu (FASB), gerekse Uluslararası Muhasebe Standartları Kurulu (IASB)'na göre finansal raporlamanın amac1, yatırımcılara, 
kreditörlere ve diğer kullanıcılara işletme ile ilgili kararlarını verirken faydalı olacak finansal bilgilerin sunulmasıdır (FASB, SFAC No.8 ${ }^{1}$ : OB3; IASB, Conceptual Framework ${ }^{2}$ : OB2).

Ülkemizde Türkiye Muhasebe Standartları Kurulu (TMSK) tarafindan yayımlanan Finansal Raporlamaya İlişkin Kavramsal Çerçeve'de ${ }^{3}$ ise, genel amaçlı finansal raporlamanın amacı, mevcut ve potansiyel yatırımcllara, borç verenlere ve kredi veren diğer taraflara, işletmeye kaynak să̆lama kararlarını verirken faydalı olacak finansal bilgiyi sağlamak şeklinde ifade edilmiştir.

Buradan hareketle çalışmamızda muhasebe bilgilerinin kalitesi, FASB ve IASB'ın bakış açısına uygun olarak "kullanıcıların ekonomik kararlar verirken ihtiyaç duydukları işletmenin finansal durumu, faaliyet sonuçları ve nakit akışları hakkında faydalı bilgilerin sağlanması" şeklinde tanımlanmıştır.

\subsection{Muhasebe Bilgilerinin Kalitesini Belirleyen Niteliksel Özellikler}

Muhasebe bilgilerinin kullanıcılara faydalı olabilmesi için sahip olması gereken niteliksel özellikler, Kavramsal Çerçeve'de temel ve destekleyici niteliksel özellikler olarak ikiye ayrılmıştır. Temel niteliksel özellikler, "ihtiyaca uygunluk (ilgililik)" ve "gerçeğe uygun sunum" şeklinde belirtilmiştir. İhtiyaca uygunluk, finansal tablolardan elde edilen bilgilerin kullanıcıların kararları ile ilişkili ve kullanım amacına uygun olmasını ifade etmektedir.

Kavramsal Çerçeve'ye göre finansal bilginin kullanıcılara faydalı olabilmesi için, finansal raporların yalnızca ihtiyaca uygun bilgileri sunması yeterli değildir. Ayrıca açıklamayı amaçladığı ekonomik olayları, gerçeğe uygun bir şekilde sunmalıdır. Gerçeğe uygun bir sunumun, tam anlamıyla sağlanabilmesi için üç özelliğe sahip olması gerekir. Buna göre sunum tam, tarafsız ve hatasız olmalıdır.

Destekleyici niteliksel özellikler ise, finansal bilginin faydalılı̆̆ını arttıran özelliklerdir. Kavramsal Çerçeve'de bu özellikler; karşılaştırılabilirlik, doğrulanabilirlik, zamanında sunum ve anlaşılabilirlik olarak sıralanmıştır.

\footnotetext{
${ }^{1}$ FASB tarafindan ilk olarak, 1978 yılında yayımlanan SFAC No.1 (İşletmelerde Finansal Raporlamanın Amaçları adlı tebliğ) ve 1980 yılında yayımlanan SFAC No.2 (Muhasebe Bilgilerinin Niteliksel Özellikleri adlı tebliğ), 2010 yılında birleştirilerek SFAC No.8 (Finansal Raporlamaya İlişkin Kavramsal Çerçeve adlı tebliğ) olarak yayımlanmıştır.

${ }^{2}$ IASC tarafindan ilk olarak, 1989 yılında Finansal Raporların Hazırlanması ve Sunulmasına İlişkin Çerçeve adıyla yayımlanmış ve 2001 yılında IASB tarafından kabul edilmiştir. Son olarak 2010 yılında güncellenmiştir.

${ }^{3}$ Ülkemizde TMSK tarafindan IASB'n yayımladığı muhasebe ve finansal raporlama standartları (IAS/IFRS), Türkçeye çevrilerek TMS/TFRS adı altında yayımlanmıştır. 2011 yılında Kamu Gözetimi, Muhasebe ve Denetim Standartları Kurumu (KGK) kurularak, TMSK'nın yerini almıştır. Finansal Raporlamaya İlişkin Kavramsal Çerçeve, IASB'ın yaptığı değişikliklerle paralellik sağlanması amacıyla 209 sıra no'lu Tebliğ ile güncellenerek 27/01/2011 tarih ve 27828 sayılı Resmi Gazete'de yayımlanmıştır.
} 


\subsection{Sermaye Piyasalarında Muhasebe Bilgilerinin Rolü ve Etkin Piyasalar Hipotezi}

Finansal piyasalarda bilginin önemi, uzun süredir araştırma konusu olmuş ve literatürde Etkin Piyasalar Hipotezi olarak yerini almıştır. Fama (1970: 383), hisse senedi fiyatlarının tüm bilgileri yansıttığı piyasaları, "etkin piyasalar" olarak tanımlamıştır. Söz konusu hipotez, menkul kıymetle ilgili tüm bilgilerin menkul kıymet fiyatları üzerindeki etkisini incelemektedir.

Literatürde üç tür piyasa etkinliğinden söz edilmektedir. Bunlar (Karan, 2001: 269): (i) geçmişteki tüm fiyat hareketlerinin fiyatlara yansıdığı zayıf formda piyasa etkinliği, (ii) halka açık tüm bilgilerin fiyatlara yansıdığı yarı-güçlü formda piyasa etkinliği ve (iii) tüm bilgilerin fiyatlara yansıdığı güçlü formda piyasa etkinliğidir.

Elmas (2012: 44), etkin bir piyasada fiyatların daima menkul kıymetlerin gerçek değerini yansıttığını belirtmektedir. Ancak gerçek piyasa koşullarında, piyasaların etkinliğini bozan ve "asimetrik bilgi" ${ }^{4}$ olarak adlandırılan bir problemle karşılaşılmaktadır. Çetinkaya (2012: 61-63), asimetrik bilgiyi, bir işlemle ilgili olarak taraflardan birinin belli bir bilgiye sahipken, diğerinin bu bilgiye sahip olmaması yani bilginin taraflar arasında simetrik dağılmaması durumu olarak tanımlamaktadır. $\mathrm{Bu}$ durumda bilgiye sahip olan taraf, diğer tarafa göre kazançlı çıkmaktadır.

Okuyan (2009: 10), piyasalarda asimetrik bilginin hatalı fiyatlamalara ve yanlış seçimlere yol açtığını belirtmektedir. Benzer şekilde Aras (2004: 91) da, asimetrik bilginin mevcut olduğu piyasalarda fiyatların ve işlem hacminin arz ve talebe göre değil, fazla bilgiye sahip olan katılımcıların tepkilerine göre belirlendiğini ifade etmektedir. Bu durum piyasa katılımcılarının finansal sisteme olan güvenini sarsarak, uzun dönemde sistemin gelişmesini ve istikrarını engellemektedir. Ayrıca ekonomik kaynakların tahsisi de olumsuz yönde etkilenmektedir.

Müslümov ve Aras (2004: 62), asimetrik bilginin oluşmasının ve kullanımının engellenmesi için piyasa düzenlemelerinin yapılmasını önermektedir. Ayrıca işletmelerin düzenleyecekleri finansal tabloların ve muhasebe bilgilerinin belirli standartları taşımasının, tam ve doğru olarak zamanında açıklanmasının önemini vurgulamaktadır.

\footnotetext{
${ }^{4}$ Asimetrik bilgi, ilk kez Akerlof (1970) tarafından ortaya atılan bir kavramdır. Akerlof (1970) makalesinde, alıcı ile satıcı arasındaki malın kalitesine ilişkin bilgi farklılığının piyasaların etkinliğini nasıl bozabileceğini, araba piyasası örneğini kullanarak açıklamıştır. Piyasadaki alıcılar, yeni bir araba alırken, arabanın kalitesi hakkında bilgi sahibi olmadıklarından, ortalama kalitede bir arabanının fiyatından ödeme yapmaya razı olurlar. Eğer satıcı iyi bir arabaya sahipse, alıcının teklif ettiği fiyattan arabasını satmak istemediğinden piyasadan çekilir. Piyasada kötü arabaya sahip satıcılar kaldığından, araba piyasasının etkinliği bozulacaktır (Akerlof, 1970: 489). Asimetrik bilgi problemi, bir süre sonra finansal piyasalarla ilgili çalışmalarda yerini almıştır.
} 


\section{MUHASEBE BILGILERININ KALITESININ ÖLÇÜMÜNDE KULLANILAN YAKLAŞIMLAR}

Muhasebe literatüründe, muhasebe bilgilerinin kalitesini farklı açılardan inceleyen çok sayıda çalışma mevcuttur. $\mathrm{Bu}$ çalışmalarda, muhasebe bilgilerinin kalitesinin tanımı ve ölçümü üzerinde bir görüş birliği bulunmamakla birlikte, FASB'ın ve IASB'ın muhasebe bilgilerinin kullanıcılara, karar aşamasında yararlı olması yaklaşımına uygun olarak, farklı boyutlar geliştirilerek ampirik analizlere konu olmaktadır. $\mathrm{Bu}$ çalışmada, muhasebe bilgilerinin kalitesi çok boyutlu ele alınarak değer ilişkisi, karların kalitesi ve nakit akışlarının tahmini yaklaşımları kullanılarak ölçülmeye çalışılacaktır.

\subsection{Değer İlişkisi}

Finansal raporlarda sunulan muhasebe bilgilerinin işletmelerin menkul kıymet fiyatlarını/getirilerini etkilemesi, literatürde "değer ilişkisi" olarak adlandırılmaktadır. Dung (2010: 1), değer ilişkisini çalışmanın, muhasebe bilgilerinin yararlılığını değerlendirmeye ve piyasa etkinliği konusunu aydınlatmaya katkıda bulunduğunu ifade etmektedir.

Bu konuda yapılmış ilk çalışmalardan biri olan Ball ve Brown (1968: 160), karların, yatırımcıları karar verirken etkilediği ve dolayısıyla hisse senedi fiyatlarına yansıdığı sonucuna ulaşmıştır. Ohlson (1991: 1), Ball ve Brown (1968)'nun çalışmalarının, modern ampirik muhasebe araştırmaları üzerinde büyük bir etkisinin olduğunu ve muhasebe bilgilerine bilgisel açıdan yaklaşılmasını sağladığını ifade etmektedir. Değer ilişkisiyle ilgili literatür her ne kadar 1960'ların sonuna kadar gitse de, Barth vd. (2001: 79), "değer ilişkisi" kavramının ilk kez kullanıldığı çalışmanın Amir vd. (1993)'ne ait olduğunu belirtmektedir. Amir vd. (1993), ABD'de geçerli olan genel kabul görmüş muhasebe ilkeleri (US GAAP)'ne uygun olarak hazırlanan finansal raporların diğer ülkelerde geçerli olan ilkelere göre hazırlanan finansal raporlara nispeten daha kaliteli muhasebe bilgileri ürettiği sonucuna varmışlardır.

\subsubsection{Değer İlişkisine İlişkin Ampirik Çalışmalar}

Muhasebe bilgilerinin değer ilişkisini ve bu ilişkinin zaman içerisindeki değişimini inceleyen çok sayıda ampirik çalışma bulunmaktadır. Aşağıda bu çalışmalara yalnızca birkaç örnek verilmiştir.

Collins vd. (1997), 1953-1993 yılları arasında NYSE, AMEX ve NASDAQ'da işlem gören firmalarda, zaman içerisinde karların ve defter değerinin birlikte değer ilişkisinin arttığını ileri sürmüşlerdir.

Francis ve Schipper (1999), ABD'de 1952-1994 yılları arasında karların ve karlardaki değişimin hisse senedi getirilerini açıklama gücünün zayıfladığını, varlıkların ve yabancı kaynakların hisse senedi fiyatlarını açıklama gücünün arttı̆̆ını, defter değeri ve karların birlikte hisse senedi fiyatlarını açıklama gücünün arttığını saptamışlardır. 
Hellström (2006), 1994-2001 döneminde Çek Cumhuriyeti ve İsveç'te muhasebe bilgilerinin değer ilişkisini araştırmıştır. Sonuçlar, Çek Cumhuriyeti'nde çalışma dönemi boyunca ve özellikle geçiş döneminin başlangıcında, değer ilişkisinin gelişmiş bir ülke olan İsveç'ten daha düşük olduğunu göstermiştir. Bununla birlikte Çek Cumhuriyeti'nde geçiş sürecindeki gelişmeye bağlı olarak, değer ilişkisi zaman içerisinde artmıştır. Bu nedenle iyi işleyen kurumlara sahip olmanın, muhasebe bilgilerinin değer ilişkisini arttırdığı sonucuna varmışlardır.

Filip ve Raffournier (2010), Romanya'da 1998-2004 yılları arasında karlar ve piyasa getirisi arasında pozitif ilişki bulunduğunu, bu ilişkinin küçük firmalarda büyük firmalardakine nispeten daha yüksek olduğunu saptamışlardır. Ayrıca pozitif kar değişikliklerinin, negatif kar değişikliklerine göre hisse senedi fiyatlarını daha çok etkilediğini tespit etmişlerdir.

Türkiye'de değer ilişkisiyle ilgili çalışmalar incelendiğinde, çalışmaların genellikle muhasebe bilgilerinin hisse senedi göstergeleriyle değer ilişkili olup olmadığına yoğunlaştığ görülmektedir. Aşağıda bu çalışmalara örnekler sunulmuştur.

Özer (1996), 1988-1992 yılları arasında, İMKB'de muhasebe karları ile hisse senedi fiyatları arasında yüksek düzeyde anlamlı ilişki tespit etmiştir. Karın unsurları olan satış hasılatı ve satılan malın maliyeti unsurları ile hisse senedi fiyatları arasında teorik beklentiye uygun ilişkiler saptamıştır.

Özer (2002), 1993-2000 yılları arasında, İMKB'de hisse senedi getirilerinin hem karların düzeyi ile hem de karlardaki değişim ile anlamlı bir ilişkiye sahip olduğunu saptamıştır. Ayrıca hisse senetlerinin değerleme sürecinde, karlardaki değişime verilen önemin, karların düzeyine verilen öneme nispeten daha fazla olduğunu tespit etmiştir.

Aktaş (2009), İMKB'de 1992-2007 yılları arasında hisse senedi fiyatları/getirileri ile finansal tablolarda sunulan varlıklar, yabancı kaynaklar, karlar, karlardaki değişim ve defter değeri arasındaki ilişkileri test ederek, muhasebe bilgilerinin yatırımcılar açısından faydalı olup olmadığını araştırmıştır. Çalışmada yaptığı detaylı analizler neticesinde, bilanço ve gelir tablosundan elde edilen özet muhasebe kalemlerinin, hisse senedi değerlemesinde önemli rol oynadığını tespit etmiştir.

Özkan ve Balsarı (2010), Türkiye'de yaşanan 1994 ve 2001 finansal krizlerinin karlar ve defter değerinin değer ilişkisi üzerindeki etkilerini araştırmışlardır. Çalışma sonucunda, 1994 krizinin karların değer ilişkisini azaltırken, defter değerinin değer ilişkisini arttırdığı görülmüştür. 2001 krizinin ise, karların değer ilişkisini azaltırken, defter değerinin değer ilişkisini etkilemediği gözlenmiştir. Her iki krizin değer ilişkisi üzerindeki etkisinin farklı olması, krizlerin farklı özellikte olmasına bağlanmıştır.

Türel (2009), Suadiye (2012), Bilgiç ve İbiş (2013), Karğın (2013) IFRS'nin kabulünden sonra muhasebe kalitesinin artıp artmadığını değer ilişkisi yaklaşımı çerçevesinde araştırmışlardır. $\mathrm{Bu}$ çalışmalar incelendiğinde, ülkemizde IFRS'nin kabulünün muhasebe bilgilerinin değer ilişkisini arttığı yönünde bir fikir birliği sağlandığı görülmektedir. 


\subsection{Karların Kalitesi}

Karların kalitesi, finansal raporlama kalitesinin temel boyutlarından birisidir. Ancak literatürde kavramsal tanımı ve ölçümü konusunda görüş birliği bulunmamaktadır. Bununla birlikte FASB'ın kar kalitesi konusuna yaklaşımı, cari dönem karlarının gelecek dönem karlarını tahmin etmede yararlı olması esasına dayanmaktadır. Aşağıda kar kalitesinin tanımına ilişkin, literatürden örnekler sunulmuştur.

Penman ve Zhang (2002: 237), gelir tablosunda raporlanan olağan karlar, gelecek karları tahmin etmede başarılı ise, yüksek kaliteli karlar olarak tanımlamışlardır. Schipper ve Vincent (2003: 97)'a göre muhasebe karları, Hicks'in tanımladığı gelire (Hicksian income) ${ }^{5}$ yaklaştıkça, kar kalitesi artmaktadır. Dechow ve Schrand (2004: 5), finansal analist bakış açısıyla kaliteli karları; firmanın cari faaliyet performansını doğru olarak yansıtan, gelecek faaliyet performansının iyi bir göstergesi olan ve firma değerini ölçmede faydalı olan karlar olarak tanımlamışlardır. Özkan vd. (2005: 131), karların kalitesinin, karı doğuran firma faaliyetleri esas alınarak belirlenebileceğini belirtmektedirler. Şöyle ki, olağan dışı faaliyetlerden sağlanan karlar sürdürülebilir değildir ve karların kalitesine katkıda bulunmazlar. Ancak olağan faaliyetlerden sağlanan karlar süreklidir ve karların kalitesini arttırmaktadır. Dechow vd. (2010: 344-345), SFAC No.1'e dayanarak kar kalitesini, "belirli bir karar vericinin kararına ilişkin olarak karların, işletmenin finansal performansının nitelikleri hakkında daha fazla bilgi sağlaması" şeklinde tanımlamışlardır.

Kar kalitesinin tanımına bağlı olarak ölçümünde kullanılan ölçütler de farklılık göstermektedir. Karların sürekliliği yaklaşımı, kar kalitesi çalışmalarında yaygın olarak kullanılan bir ölçüttür. Dechow vd. (2010: 350)'ne göre bu yaklaşım, süreklilik gösteren karların, menkul kıymet değerleme modellerine daha iyi bir girdi sağlayacağı ve bu nedenle daha az sürekli olan karlara nispeten yüksek kalitede olacağı varsayımına dayanmaktadır. Call (2007: 9), karların dalgalı olmasının, genellikle karların düşük kaliteli olduğu ve yatırımcılar için faydalı bilgi olma özelliğini yitirdiği şeklinde algılandığını belirtmektedir.

\subsubsection{Kar Kalitesine İlişkin Ampirik Çalışmalar}

Kar kalitesinin tespitine yönelik çalışmalar incelendiğinde, çalışmaların tahakkuklar ve nakit akışları çerçevesinde yürütüldüğü ve özünde tahakkuk esaslı muhasebe yöntemi ile nakit esaslı muhasebe yönteminin karşılaştırıldığg görülmektedir.

Dechow (1994), ABD'de 1960-1989 yılları arasında kısa vadede tahakkukların hisse senedi getirileriyle ilişkisinin nakit akışlarına nispeten daha güçlü olduğunu tespit etmiştir. Bu çalışma, tahakkuk muhasebesinin faydalarına dikkat çekmiştir. Nakit akışlarının yaşanan zamanlama ve eşleştirme problemlerinden dolayı performans ölçümünde tahakkuklara göre

\footnotetext{
${ }^{5}$ Hicks (1939), ekonomi temelli yaklaşımla geliri; firmanın dönem başı ve dönem sonundaki varlıkları birbirine eşit olacak şekilde, dönem boyunca harcanabilecek miktar olarak tanımlamıştır (Schipper ve Vincent, 2003: 97).
} 
daha "ilkel" bir araç olduğu, tahakkukların ise, karların firma performansını ölçme kabiliyetini arttırdığını öne sürmüştür.

Sloan (1996), çalışmasında ilk kez karları, tahakkuklar ve nakit akışları şeklinde iki bileşene ayırmıştır. ABD'de 1962-1991 yıllarını kapsayan çalışmasında, tahakkuk bileşeninin karlar içerisinde payının arttıkça karların sürekliliğinin düştüğünü saptamıştır. Araştırmacı, karların nakit akış bileşeninin tahakkuklara nispeten daha güvenilir ve kaliteli olduğunu ileri sürmüştür.

Bartov vd. (2001), araştırmaları sonucunda, Anglo-Sakson ülkelerde karların hisse senedi getirilerini açıklamada nakit akışlarından daha üstün olduğunu tespit etmişlerdir. Ayrıca değişkenler arasındaki ilişkinin ulusal raporlama rejimlerine ve kurumsal faktörlere bağlı olduğuna dikkat çekmişlerdir.

Richardson vd. (2005), ABD'de 1962-2001 yılları arasında tahakkukları alt bileşenlerine ayırmışlar ve her bir bileşene güvenilirlik düzeyi belirlemişlerdir. Düşük güvenilirlikteki tahakkuk alt bileşenlerinin, karların sürekliliğini düşürdügünü ancak yatırımcıların düşük kar sürekliliğine tam olarak tepki vermediğini ve bu durumun hisse senetlerinin yanlış fiyatlandırılmasına sebep olduğunu ileri sürmüşlerdir.

İç ve Aygün (2009), ülkemiz sermaye piyasasında 1997-2007 yılları arasında kardaki ve nakit akışlarındaki değişimin yatırımcılara bilgi sağladığını ve yatırımcının pozitif yöndeki değişime olumlu tepki verdiğini tespit etmişlerdir. Ayrıca kardaki değişimin yatırımcıları, nakit akışlarındaki değişimden daha fazla etkilediğini saptamışlardır.

Yel (2012), 1992-2003 yılları arasında İMKB'de işlem gören firmalarda cari dönem nakit akışlarının gelecek dönem anormal hisse senedi getirileri üzerinde tahakkuklara göre daha etkili olduğu sonucuna varmıştır.

Dichev vd. (2013), çalışmalarında anket ve mülakat yöntemlerini kullanarak finanstan sorumlu genel müdürlerin (CFO) kar kalitesi hakkındaki görüşlerine yer vermişlerdir. CFO'lar kaliteli karların, sürdürülebilir ve tekrarlanabilir özellikte olması gerektiği şeklinde görüş sunmuşlardır. Ayrıca alternatif muhasebe yöntemlerinin kullanımındaki tutarlılığın, kar kalitesini etkilediğini vurgulamışlardır.

\subsection{Nakit Akıșlarının Tahmin Edilebilirliği}

Finansal raporlamanın ana amaçlarından biri, işletmelerin gelecek nakit akışlarını tahmin ederken finansal tablo kullanıcılarına yardımcı olacak bilgilerin sağlanmasıdır. Dolayısıyla bir işletmenin nakit akışları tahmin edilebiliyorsa, muhasebe bilgilerinin kaliteli olduğu söylenebilir.

Kavramsal Çerçeve'ye göre, bir işletmenin belirli bir dönemdeki nakit akışlarına ilişkin bilgi, işletmenin faaliyetlerinin anlaşılmasına, finansman ve yatırım faaliyetleri ile likidite ve borç ödeme gücünün değerlendirilmesine ve finansal performansla ilgili diğer bilgilerin yorumlanmasına yardımcı olmaktadır. Bununla birlikte gelecek dönem nakit 
akışlarının tahmini, firma ile ilgili kararlar verilmesinde oldukça önemli bir yere sahiptir. Cheng ve Hollie (2005: 2), gelecek nakit akışlarının tahmin edilmesinin, likidite ve iflas analizlerinde kullanıldığını ifade ederken, Farshadfar ve Monem (2013: 111), firma değerleme ve yatırım analizlerinde önemli olduğuna dikkat çekmektedirler.

Finansal tablo kullanıcıları, işletmelerin nakit ve nakit benzeri değerleri yaratma kabiliyetini değerlendirmek ve işletmede nakit akışlarından nasıl yararlanıldığını analiz etmek için nakit akış tablolarına ihtiyaç duymaktadır. TMS-7 Nakit Akış Tabloları standardına göre, tarihi nakit akış bilgisi; gelecekteki nakit akışlarının tutarı, zamanlaması ve kesinliğinin göstergesi olarak kabul edilmektedir. Ayrıca bu bilgiler, gelecek nakit akışlarına ilişkin geçmişte yapılan değerlendirmelerin doğruluğunun kontrol edilmesi ve karlılık, net nakit akışları ve fiyat değişiminin etkileri arasındaki ilişkinin değerlendirilmesinde de kullanılmaktadır.

Nakit akışlarının tahmini ile ilgili çalışmaların dayanağı, FASB'ın 1978 yılında yayımladığı "İşletmelerde Finansal Raporlamanın Amaçları" adlı tebliğdir (SFAC No.1). Bu tebliğde, işletmelerin gelecek nakit akışlarının ve bu nakit akışlarını devam ettirebilme yeteneğinin belirlenmesinde, tahakkuk eden karların cari nakit akışlarından daha iyi bir gösterge olduğu ifade edilmektedir.

FASB'ın bu önermesini test eden ampirik çalışmaların sonuçları çelişkilidir. Literatürde temel olarak iki görüş bulunmaktadır. İlk görüşe göre, tahakkuk eden karlar, nakit akışlarına nispeten daha üstündür. Zira tahakkuklar, nakit akışlarında söz konusu olan zamanlama ve eşleştirme problemlerini düzeltmektedir. İkinci görüşe göre, nakit akışları tahakkuk eden karlardan üstündür. Çünkü karlar, bir yandan manipüle edilerek kar yönetimi (earnings management) uygulamalarına konu olmakta, diğer yandan da işletmeler tarafindan uygulanan muhasebe politikalarından etkilenmektedir. Nakit akışlarında ise, bu problemlerle karşılaşılmamaktadır.

\subsubsection{Nakit Akışlarının Tahminine İlişkin Ampirik Çalışmalar}

Nakit akışlarının tahminiyle ilgili ampirik çalışmalarda, FASB'ın önermesi test edilmektedir. Ampirik çalışmalarda elde edilen çelişkili sonuçlar, konuyla ilgili fikir birliği sağlanmasını güçleştirmektedir.

Finger (1994), ABD'de 1935-1987 yılları arasında karların ve nakit akışlarının bir yıldan sekiz yıla kadar gelecek dönem nakit akışlarını tahmin etme kabiliyetini araştırmıştır. Kısa vadede nakit akışlarının tahmin edilmesinde, nakit akışlarının karlara nispeten daha iyi bir gösterge olduğunu tespit etmiştir. Bununla birlikte uzun vadede her iki kalemin, neredeyse aynı düzeyde tahmin gücüne sahip olduğunu gözlemiştir.

Dechow vd. (1998), ABD'de 1963-1992 yılları arasında gelecek dönem nakit akışlarını tahmin etmede karların, nakit akışlarına nispeten daha başarılı olduğunu saptamışlardır. 
Ayrıca karların ve nakit akışlarının tahmin gücü arasındaki farkın, firmaların nakit döngüsünden etkilendiğini gözlemişlerdir.

Barth vd. (2001), 1987-1996 yılları arasında bileşenlerine ayrılmış karların, gelecek dönem nakit akışlarını, nakit akışlarına nispeten daha iyi tahmin ettiği sonucuna varmışlardır.

Kim ve Kross (2005), ABD'de 1973-2000 yılları arasında karların gelecek nakit akışlarını tahmin etme kabiliyetinin, son 28 yılda genel olarak arttığını tespit etmişlerdir.

Aktaş ve Karğın (2012), Türkiye'de 2008-2010 yılları arasında gelecek dönem nakit akışlarının tahmin edilmesinde nakit akışlarının, karlara nispeten daha iyi bir gösterge olduğunu tespit etmişlerdir. Ayrıca pozitif nakit akışlarına sahip, toplam varlıkları yüksek olan, nakit ve faaliyet döngüleri kısa olan firmalarda, gelecek nakit akışlarının daha yüksek düzeyde tahmin edilebildiğini saptamışlardır.

Lopez ve Nichols (2012), ABD ve Meksika'da profesyonel olmayan yatırımciların kararlarını verirken karları mı, yoksa nakit akışlarını mı daha çok kullandıklarını incelemişlerdir. ABD'de katılımcıların ağırlıklı olarak karları kullanırlarken, Meksika'da nakit akışlarını kullandıklarını tespit etmişlerdir.

\section{MUHASEBE BİLGILERINIIN KALITTESINII ÖLÇMEYE YÖNELİK BİR UYGULAMA}

Çalışmanın bu bölümünde, sermaye piyasalarında sunulan muhasebe bilgilerinin kalitesini ölçmeye yönelik bir uygulama sunulacaktır. Uygulama; değer ilişkisi, karların kalitesi ve nakit akışlarının tahmin edilebilirliği çerçevesinde üç boyutlu olarak gerçekleştirilmiştir.

\section{1. Örneklem ve Veriler}

Çalışmanın örneklemini, hisse senetleri Borsa İstanbul'da işlem gören firmalar oluşturmaktadır. Finans sektöründe faaliyet gösteren firmalar kapsam dışı bırakılmıştır. Çalışma döneminin başlangıç yılı olarak, uluslararası finansal raporlama standartlarının ülkemizde uygulanmaya başlandığı yıl olan 2005 yılı seçilmiştir.

Çalışmada kullanılan bilanço ve gelir tablosu verileri ile hisse senedi sayıları ve hisse senedi fiyatları, FINNET veri tabanından sağlanmıştır. Nakit akış tablolarında raporlanan veriler ise, Borsa İstanbul'un ve Kamuyu Aydınlatma Platformu'nun resmi internet sitelerinden sağlanan bağımsız denetimden geçmiş nakit akış tablolarından, tek tek toplanmak suretiyle elde edilmiştir. Hisse başına veriler, Excel programı aracılığıyla hesaplanmıştır.

\subsection{Araştırmanın Yöntemi}

Çalışmada muhasebe bilgilerinin kalitesinin ölçümünde basit ve çoklu regresyon analizi kullanılmıştır. Regresyon çözümlemeleri, yatay kesit veriler kullanılarak "sıradan en 
küçük kareler" yöntemiyle gerçekleştirilmiştir. Analizlerde, Gretl Ekonometri Yazılımı 1.9.14 versiyonu kullanılmıştır.

Regresyon analizlerinde bağımlı değişkenin ve hataların normal dağılım gösterdikleri varsayılır (Özdamar, 2004: 197). Bu nedenle veri setinde bulunan aykırı gözlemler tespit edilerek veri setinden çıkarılmıştır. Çoklu regresyon analizlerinde, bağımsız değişkenler arasında çoklu doğrusal bağlantı (multicollinearity) probleminin olmadığını göstermek amaciyla regresyon çözümlemelerinin tümünde, varyans şişkinlik faktör (VIF) değerleri elde edilerek regresyon sonuçlarıyla birlikte raporlanmıştır.

\subsection{Model ve Değişkenler}

Muhasebe bilgilerinin kalitesinin ölçümünde dört model kullanılmıştır. Modellerde yer alan değişkenler, literatüre uygun olarak hisse başına değerleri ile kullanılmıştır. Herrmann vd. (2000: 52), değişkenlerin değerlerinin bu şekilde küçültülmesinin, hem firma büyüklüklerinin etkilerini hem de değişen varyanslılık (heteroscedasticity) probleminin kontrol altında tutulmasını sağladığını belirtmektedir.

Değer ilişkisinin test edilmesinde Ohlson (1995) modeli kullanılmıştır. Ohlson (1995) bir firmanın piyasa değerini; defter değeri ve karların doğrusal bir fonksiyonu olarak ifade etmiştir. Buna göre çalışmada kullanılan ilk model aşağıdaki gibidir:

$H B P D_{i t+1}=\beta_{0}+\beta_{1} H B D D_{i t}+\beta_{2} H B K_{i t}+\varepsilon_{i t}$

Modelde $H B P D_{i t+1}=\mathrm{i}$ hisse senedinin $\mathrm{t}+1$ yılı hisse başına piyasa değerini, $H B D D_{i t}=$ i hisse senedinin $\mathrm{t}$ yılı hisse başına defter değerini, $H B K_{i t}=\mathrm{i}$ hisse senedinin $\mathrm{t}$ yllı hisse başına net karını, $\varepsilon_{i t}=$ hata terimini ifade etmektedir.

Çalışmamızda kar kalitesinin değerlendirilmesinde, karların sürekliliği yaklaşımı kullanılmıştır. Buna göre çalışmamızda, ilk aşamada kullanılan model aşağıdaki gibidir:

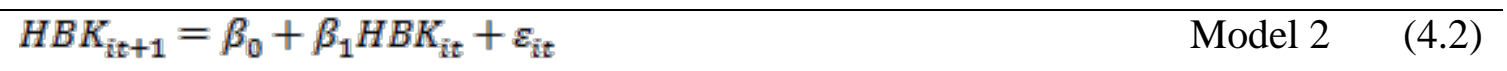

Modelde $H B K_{i t+1}=$ i firmasının gelecek dönem karlarının hisse başına değerini, $H B K_{i t}=$ i firmasının cari dönem karlarının hisse başına değerini ifade etmektedir. Ayrıca çalışmamızda, Sloan (1996)'nın nakit akışları ve tahakkukların sürekliliğini hakkındaki hipotezini test etmek amacıyla aşağıdaki model kullanılmıştır:

$H_{B K_{i t+1}}=\beta_{0}+\beta_{1}$ HBFNA $_{i t}+\beta_{2}$ HBTAH $_{i t}+\varepsilon_{\text {it }} \quad$ Model $3 \quad$ (4.3)

Modelde $H B F N A_{i t}=$ i firmasının cari dönem faaliyetlerden sağlanan nakit akışlarının hisse başına değerini ve $H B T A H_{i t}=\mathrm{i}$ firmasının cari dönem tahakkuklarının hisse başına değerini ifade etmektedir. Tahakkuk bileşeni, karlar ve faaliyetlerden sağlanan nakit akışları arasındaki fark olarak hesaplanmıştır. 
Nakit akışlarının tahmin edilmesinde FASB'ın önermesini test etmek üzere aşağıdaki model kullanılmıştır:

HBFNA $_{i t+1}=\beta_{0}+\beta_{1}$ HBFNA $_{i t}+\beta_{2} H B K_{i t}+\varepsilon_{i t} \quad$ Model $4 \quad$ (4.4)

Modelde $H B F N A_{i t+1}=\mathrm{i}$ firmasının gelecek dönem faaliyetlerden sağlanan nakit akışlarının hisse başına değerini, $H B F N A_{i t}=\mathrm{i}$ firmasının cari dönem faaliyetlerden sağlanan nakit akışlarının hisse başına değerini ve $H B K_{i t}=$ i firmasının cari dönem karlarının hisse başına değerini ifade etmektedir.

\subsection{Bulgular}

Çalışmanın bu kısmında muhasebe kalitesinin üç boyutuna ilişkin bulgular ayrı ayrı raporlanmıştır. Ele alınan ilk kalite boyutu olan değer ilişkisini test eden Model 1'e ilişkin sonuçlar, aşağıda Tablo 1'de sunulmuştur.

Tablo 1: Değer İlişskisi Modeline Ait Yıllık, Toplulaştırılmış ve Sektörel Regresyon Sonuçları

\begin{tabular}{|c|c|c|c|c|c|c|c|}
\hline \multicolumn{8}{|c|}{$H B P D_{\text {it }+1}=\beta_{0}+\beta_{1} H B D D_{\text {it }}+\beta_{2} H B K_{\text {it }}+\varepsilon_{\text {it }}$} \\
\hline Panel A & $\mathbf{N}$ & $\begin{array}{c}\boldsymbol{\beta}_{0} \\
\text { (t-ist.) }\end{array}$ & $\begin{array}{c}\beta_{1} \\
\text { (t-ist.) }\end{array}$ & $\begin{array}{c}\boldsymbol{\beta}_{2} \\
\text { (t-ist.) }\end{array}$ & $\bar{R}^{2}$ & F-ist. & VIF \\
\hline 2005 & 167 & $\begin{array}{c}0,9417 \\
(0,5683)\end{array}$ & $\begin{array}{c}1,7621 \\
(6,2418)^{* * *}\end{array}$ & $\begin{array}{c}1,5575 \\
(0,9829)\end{array}$ & 0,3851 & $52,9794 * * *$ & 2,1660 \\
\hline 2006 & 170 & $\begin{array}{c}1,5217 \\
(1,1631)\end{array}$ & $\begin{array}{c}1,3574 \\
(5,3162)^{* * *}\end{array}$ & $\begin{array}{c}0,7621 \\
(0,6245)\end{array}$ & 0,3606 & $48,6624 * * *$ & 2,8620 \\
\hline 2007 & 170 & $\begin{array}{c}0,5866 \\
(0,7758)\end{array}$ & $\begin{array}{c}1,0813 \\
(6,0230)^{* * *}\end{array}$ & $\begin{array}{c}2,4747 \\
(2,9558)^{* * *}\end{array}$ & 0,4516 & $70,5739 * * *$ & 2,0090 \\
\hline 2008 & 176 & $\begin{array}{c}1,5821 \\
(2,7685)^{* * *}\end{array}$ & $\begin{array}{c}0,6913 \\
(9,6700)^{* * *}\end{array}$ & $\begin{array}{c}1,3756 \\
(2,2324)^{* *}\end{array}$ & 0,5850 & $124,3239 * * *$ & 1,9350 \\
\hline 2009 & 179 & $\begin{array}{c}0,6427 \\
(0,4379)\end{array}$ & $\begin{array}{c}2,3010 \\
(10,2722)^{* * *}\end{array}$ & $\begin{array}{c}-1,6235 \\
(-0,8391)\end{array}$ & 0,3697 & $53,2073 * * *$ & 1,0310 \\
\hline 2010 & 192 & $\begin{array}{c}-2,3631 \\
(-1,1051)\end{array}$ & $\begin{array}{c}4,4212 \\
(8,4596)^{* * *}\end{array}$ & $\begin{array}{c}-2,7076 \\
(-0,8228)\end{array}$ & 0,3122 & $44,3575 * * *$ & 1,3640 \\
\hline 2011 & 209 & $\begin{array}{c}-0,3355 \\
(-0,2148) \\
\end{array}$ & $\begin{array}{c}2,7479 \\
(6,4925)^{* * *}\end{array}$ & $\begin{array}{c}-0,1332 \\
(-0,0738) \\
\end{array}$ & 0,3010 & $45,7782 * * *$ & 2,2090 \\
\hline 2012 & 238 & $\begin{array}{c}-1,0394 \\
(-1,0736) \\
\end{array}$ & $\begin{array}{c}2,6097 \\
(11,0918)^{* * *}\end{array}$ & $\begin{array}{c}2,4999 \\
(2,1287)^{* *}\end{array}$ & 0,4273 & $89,4039 * * *$ & 1,2130 \\
\hline \multicolumn{8}{|l|}{ Panel B } \\
\hline TÜM & 1551 & $\begin{array}{c}1,4845 \\
(2,8936)^{* * *}\end{array}$ & $\begin{array}{c}1,6781 \\
(22,2343)^{* * *}\end{array}$ & $\begin{array}{c}2,1167 \\
(4,5749) * * *\end{array}$ & 0,4229 & $568,8654 * * *$ & 1,7540 \\
\hline SINAİ & 1165 & $\begin{array}{c}1,3490 \\
(2,1465)^{* *}\end{array}$ & $\begin{array}{c}1,7442 \\
(19,3671)^{* * *}\end{array}$ & $\begin{array}{c}1,4192 \\
(2,4887)^{* *}\end{array}$ & 0,4275 & $435,5710 * * *$ & 1,9430 \\
\hline HİZMET & 386 & $\begin{array}{c}1,4922 \\
(1,8143) *\end{array}$ & $\begin{array}{c}1,6011 \\
(11,3043)^{* * *}\end{array}$ & $\begin{array}{c}4,3515 \\
(6,1786)^{* * *}\end{array}$ & 0,4058 & $132,4766^{* * *}$ & 1,1930 \\
\hline
\end{tabular}

Not: Panel A, (t) yılını; N, gözlem sayısını temsil etmektedir. *,**,*** sırasıyla \%10, \%5, \%1 düzeyinde istatistiksel olarak anlamlılığ bağlantı problemi yoktur.

Tablo 1 iki panel düzeyinde oluşturulmuştur. Panel A, Model 1'e ilişkin regresyon sonuçlarını yıllara göre, Panel B ise, 2005-2012 yıllarına ait toplulaştırılmış veriler ile sınai ve hizmet olmak üzere sektörel bazda göstermektedir. 
Model sonuçları dikkate alındığında, bilanço ve gelir tablosundan elde edilen özet muhasebe bilgilerinin (defter değeri ve karların) hisse senetlerinin piyasa değerini açıklama düzeyi yıllık ortalama $\% 40$, toplulaştırılmış verilerde $\% 42$ civarındadır. Toplulaştırılmış verilerin sonuçlarına göre, hisse senedi değerlemesinde karların rolünün, defter değerine nispeten daha yüksek olduğu görülmüştür. Sonuçlar sektörel açıdan analiz edildiğinde, sınai sektöründe defter değerinin rolünün karlara nispeten bir miktar daha fazlayken, hizmet sektöründe karların rolünün oldukça fazla olduğu görülmüştür. Dolayısıyla muhasebe bilgilerinin değer ilişkisinin, firmaların faaliyet gösterdikleri sektörlere göre farklılık gösterdiği söylenebilir.

İkinci kalite boyutu olan karların sürekliliğini test eden Model 2'ye ilişsin sonuçlar, aşağıda Tablo 2'de sunulmuştur.

Tablo 2: Bileşenlerine Ayrılmamış Kar Kalitesi Modelinin Yıllık, Toplulaştırılmış ve Sektörel Regresyon Sonuçları

\begin{tabular}{|c|c|c|c|c|c|}
\hline \multicolumn{6}{|c|}{$H B K_{i t+1}=\beta_{0}+\beta_{1} H B K_{i t}+\varepsilon_{i t}$} \\
\hline Panel A & $\mathbf{N}$ & $\begin{array}{c}\beta_{0} \\
\text { (t-ist.) }\end{array}$ & $\begin{array}{c}\beta_{1} \\
(t-i s t .)\end{array}$ & $\bar{R}^{2}$ & F-ist. \\
\hline 2005 & 217 & $\begin{array}{c}0,0995 \\
81,6543)^{*}\end{array}$ & $\begin{array}{c}1,0501 \\
(26,5707)^{* * *}\end{array}$ & 0,7655 & $706,0004 * * *$ \\
\hline 2006 & 205 & $\begin{array}{c}0,2383 \\
(2,6341)^{* * *}\end{array}$ & $\begin{array}{c}0,8588 \\
(14,5699)^{* * *}\end{array}$ & 0,5088 & $212,2811 * * *$ \\
\hline 2007 & 211 & $\begin{array}{c}-0,2637 \\
(-1,8464)^{*}\end{array}$ & $\begin{array}{c}1,0170 \\
(10,7910)^{* * *}\end{array}$ & 0,3547 & $116,4450 * * *$ \\
\hline 2008 & 193 & $\begin{array}{c}0,2025 \\
(2,0987)^{* *}\end{array}$ & $\begin{array}{c}0,2625 \\
(2,7441)^{* * *}\end{array}$ & 0,0329 & $7,5303 * * *$ \\
\hline 2009 & 213 & $\begin{array}{c}0,3196 \\
(3,6271)^{* * *}\end{array}$ & $\begin{array}{c}0,0208 \\
(0,1240)\end{array}$ & $-0,0047$ & 0,0154 \\
\hline 2010 & 208 & $\begin{array}{c}-0,0021 \\
(-0,0255)\end{array}$ & $\begin{array}{c}1,4504 \\
(11,1727)^{* * *}\end{array}$ & 0,3743 & $124,8298 * * *$ \\
\hline 2011 & 266 & $\begin{array}{c}0,1109 \\
(1,2761)\end{array}$ & $\begin{array}{c}0,6535 \\
(14,2550)^{* * *}\end{array}$ & 0,4328 & $203,2052 * * *$ \\
\hline \multicolumn{6}{|l|}{ Panel B } \\
\hline TÜM & 1531 & $\begin{array}{c}0,1408 \\
(3,7214)^{* * *}\end{array}$ & $\begin{array}{c}0,7786 \\
(27,9700)^{* * *}\end{array}$ & 0,3380 & $782,3212 * * *$ \\
\hline SINAİ & 1169 & $\begin{array}{c}0,1423 \\
(3,0640)^{* * *}\end{array}$ & $\begin{array}{c}0,8209 \\
(25,9836)^{* * *}\end{array}$ & 0,3660 & $675,1478 * * *$ \\
\hline HİZMET & 362 & $\begin{array}{c}0,1665 \\
(3,1239)^{* * *}\end{array}$ & $\begin{array}{c}0,4137 \\
(7,0786)^{* * *}\end{array}$ & 0,1197 & $50,1064 * * *$ \\
\hline
\end{tabular}

Not: Panel A, (t) y1lını; N, gözlem sayısını temsil etmektedir. *,**,*** sırasıyla \%10, \%5, \%1 düzeyinde istatistiksel olarak anlamlılı̆̆ ifade etmektedir.

Cari dönem karlarının gelecek dönem karlarını açıklama düzeyi yıllık ortalama $\% 35$, toplulaştırılmış verilerde yaklaşık \%34'tür. Karların süreklilik katsayısı $\left(\beta_{1}\right)$, toplulaştırılmış verilerde 0,78 düzeyindedir. Dolayısıyla karların sürekli (kaliteli) olduğu sonucuna varılabilir. Sektörel analizlere bakıldığında, sınai sektöründe karların sürekliliği hizmet sektörünün iki katıdır. Cari dönem ve gelecek dönem karları arasındaki ilişkinin 2009 yılında istatistiksel 
olarak anlamsız olduğu görülmüştür. Buradan hareketle 2009 Küresel Finansal Kriz'in Borsa İstanbul'da karların sürekliliğini ve tahmin edilebilirliğini olumsuz yönde etkilemiş olduğu söylenebilir.

Cari dönem karlarının nakit akışları ve tahakkuklar şeklinde bileşenlerine ayrıldığı Model 3, hem bileşenlerin gelecek dönem karları ile arasındaki ilişkiyi hem de bileşenlerin süreklilik katsayılarını göstermesi açısından önemlidir. Model 3'e ilişkin sonuçlar, aşağıda Tablo 3'de sunulmuştur.

Tablo 3: Bileşenlerine Ayrılmış Kar Kalitesi Modelinin Yıllık, Toplulaştırılmış ve Sektörel Regresyon Sonuçları

\begin{tabular}{|c|c|c|c|c|c|c|c|}
\hline \multicolumn{8}{|c|}{$H B K_{\text {it }+1}=\beta_{0}+\beta_{1} H B F N A_{i t}+\beta_{2} H B T A H_{\text {it }}+\varepsilon_{\text {it }}$} \\
\hline Panel A & $\mathbf{N}$ & $\begin{array}{c}\beta_{0} \\
\text { (t-ist.) }\end{array}$ & $\begin{array}{c}\beta_{1} \\
\text { (t-ist.) }\end{array}$ & $\begin{array}{c}\beta_{2} \\
\text { (t-ist.) }\end{array}$ & $\bar{R}^{2}$ & F-ist. & VIF \\
\hline 2005 & 210 & $\begin{array}{c}0,0382 \\
(0,6703)\end{array}$ & $\begin{array}{c}1,1785 \\
(20,4892)^{* * *}\end{array}$ & $\begin{array}{c}1,0688 \\
(12,6521)^{* * *}\end{array}$ & 0,6757 & $218,7602^{* * *}$ & 1,2300 \\
\hline 2006 & 203 & $\begin{array}{c}0,1823 \\
(2,3590)^{* *}\end{array}$ & $\begin{array}{c}0,8652 \\
(13,9625)^{* * *}\end{array}$ & $\begin{array}{c}0,4873 \\
(5,1838)^{* * *}\end{array}$ & 0,5183 & $109,6814^{* * *}$ & 1,7030 \\
\hline 2007 & 201 & $\begin{array}{c}-0,0949 \\
(-0,9218) \\
\end{array}$ & $\begin{array}{c}0,3758 \\
(3,4385)^{* * *}\end{array}$ & $\begin{array}{c}0,0498 \\
(0,2988)\end{array}$ & 0,0766 & $9,2922 * * *$ & 1,7600 \\
\hline 2008 & 185 & $\begin{array}{c}0,1583 \\
(2,4496)^{* *}\end{array}$ & $\begin{array}{c}0,5169 \\
(7,4642)^{* * *}\end{array}$ & $\begin{array}{c}0,3640 \\
(5,6249)^{* * *}\end{array}$ & 0,2570 & $32,8158^{* * *}$ & 1,1490 \\
\hline 2009 & 212 & $\begin{array}{c}0,0822 \\
(2,1941)^{* *}\end{array}$ & $\begin{array}{c}0,6261 \\
(9,0098)^{* * *}\end{array}$ & $\begin{array}{c}0,4500 \\
(5,6993) * * *\end{array}$ & 0,3210 & $50,8714 * * *$ & 4,2888 \\
\hline 2010 & 203 & $\begin{array}{c}0,1320 \\
(1,5701) \\
\end{array}$ & $\begin{array}{c}0,7525 \\
(5,5854)^{* * *} \\
\end{array}$ & $\begin{array}{c}0,6817 \\
(3,7670)^{* * *}\end{array}$ & 0,1286 & $15,9036^{* * *}$ & 2,4080 \\
\hline 2011 & 264 & $\begin{array}{c}0,1820 \\
(2,3379)^{* *}\end{array}$ & $\begin{array}{c}0,5193 \\
(8,9095)^{* * *}\end{array}$ & $\begin{array}{c}0,5078 \\
(10,5649)^{* * *}\end{array}$ & 0,3186 & $62,4974 * * *$ & 1,4460 \\
\hline \multicolumn{8}{|l|}{ Panel B } \\
\hline TÜM & 1525 & $\begin{array}{c}0,0763 \\
(2,0857)^{* *}\end{array}$ & $\begin{array}{c}0,8334 \\
(30,3134)^{* * *}\end{array}$ & $\begin{array}{c}0,5306 \\
(15,4482)^{* * *}\end{array}$ & 0,3797 & $467,4687 * * *$ & 1,6050 \\
\hline SINAİ & 1163 & $\begin{array}{c}0,0743 \\
(1,6733)^{*}\end{array}$ & $\begin{array}{c}0,8849 \\
(28,5128)^{* * *}\end{array}$ & $\begin{array}{c}0,5462 \\
(14,0208)^{* * *}\end{array}$ & 0,4153 & $413,7087 * * *$ & 1,5580 \\
\hline HİZMET & 362 & $\begin{array}{c}0,1345 \\
(2,4676)^{* *}\end{array}$ & $\begin{array}{c}0,4359 \\
(7,4202)^{* * *}\end{array}$ & $\begin{array}{c}0,3109 \\
(4,3442)^{* * *}\end{array}$ & 0,1318 & $28,4111^{* * *}$ & 2,0240 \\
\hline
\end{tabular}

Not: Panel A, (t) yılını; N gözlem sayısını temsil etmektedir. *,**,*** sırasıyla \%10, \%5, \%1 düzeyinde istatistiksel olarak anlamlılığı ifade etmektedir. VIF $<10$ ise, açıklayıcı değişkenler arasında çoklu doğrusal bağlantı problemi yoktur.

Çalışmada karların, nakit akışları ve tahakkuk bileşenlerinin süreklilik özelliklerini görebilmek amacıyla, karlar bileşenlerine ayrılarak ikinci bir model kullanılmıştır. Nakit akışları ve tahakkukların gelecek karları birlikte açıklama gücü \%38'dir. Regresyon sonuçları incelendiğinde, teorik beklentiye uygun olarak nakit akışlarının sürekliliğinin $\left(\beta_{1}\right)$, tahakkuklara $\left(\beta_{2}\right)$ göre daha yüksek olduğu görülmüştür. Bununla birlikte hizmet sektöründe 
hem nakit akışlarının hem de tahakkukların sürekliliği, sınai sektörüne göre daha düşük düzeydedir.

Model 2 ve Model 3 süreklilik katsayıları açısından incelenecek olursa, toplulaştırılmış verilerde cari dönem karlarının süreklilik katsayısının 0,77 iken, nakit akışları ve tahakkuk bileşenlerinin süreklilik katsayılarının sırasıyla 0,83 ve 0,53 olduğu görülmektedir. Buna göre tahakkukların, karların sürekliliğini azalttığı söylenebilir.

Bununla birlikte bileşenlerine ayrılmamış (Model 2) ve bileşenlerine ayrılmış (Model 3) kar modellerinin göreceli açıklama güçleri hesaplanmıştır. Sonuçlar, aşağıda Tablo 4'de özetlenmiştir.

Tablo 4: Bileşenlerine Ayrılmış ve Ayrılmamış Kar Modellerinin Göreceli Açıklama Güçleri

\begin{tabular}{|cccc|}
\hline Panel A & $\overline{\boldsymbol{R}}^{2} \mathbf{M} 2$ & $\overline{\boldsymbol{R}}^{2} \mathbf{M} 3$ & GAG \\
\hline 2005 & 0,7655 & 0,6757 & 0,0898 \\
2006 & 0,5088 & 0,5183 & $-0,0095$ \\
2007 & 0,3547 & 0,0766 & 0,2782 \\
2008 & 0,0329 & 0,2570 & $-0,2241$ \\
2009 & $-0,0047$ & 0,3210 & $-0,3256$ \\
2010 & 0,3743 & 0,1286 & 0,2457 \\
2011 & 0,4328 & 0,3186 & 0,1142 \\
Ortalama & 0,3520 & 0,3280 & 0,0241 \\
\hline Panel B & & & \\
\hline TÜM & 0,3380 & 0,3797 & $-0,0417$ \\
SINAİ & 0,3660 & 0,4153 & $-0,0494$ \\
HïMET & 0,1197 & 0,1318 & $-0,0121$ \\
\hline
\end{tabular}

Not: $\bar{R}^{2} \mathrm{M} 2$ ve $\bar{R}^{2} \mathrm{M} 3$, sırasıyla Model 2 (bileşenlerine ayrılmamış model) ve Model 3 (bileşenlerine ayrılmış model)'e ait düzeltilmiş belirlilik katsayıları; GAG, göreceli açıllama gücü $\left(\bar{R}^{2} \mathrm{M} 2-\bar{R}^{2} \mathrm{M} 3\right)$.

Toplulaştırılmış ve sektörel veri sonuçları dikkate alındığında bileşenlerine ayrılmış kar modeli (Model 3), bileşenlerine ayrılmamış kar modelinden (Model 2) göreceli olarak üstün bulunmuştur.

Son kalite boyutu olan cari dönem nakit akışları ve karlar ile gelecek dönem nakit akışları arasındaki ilişkiyi test eden Model 4'e ilişkin regresyon sonuçları aşağıda Tablo 5'de özetlenmiştir. 
Tablo 5: Nakit Akışlarının Tahminine İlişkin Yılık, Toplulaştırılmış ve Sektörel Regresyon Sonuçları

\begin{tabular}{|c|c|c|c|c|c|c|c|}
\hline \multicolumn{8}{|c|}{$H B F N A_{i t+1}=\beta_{0}+\beta_{1} H B F N A_{i t}+\beta_{2} H B K_{i t}+\varepsilon_{i t}$} \\
\hline Panel A & $\mathbf{N}$ & $\begin{array}{c}\boldsymbol{\beta}_{0} \\
\text { (t-ist.) }\end{array}$ & $\begin{array}{c}\beta_{1} \\
\text { (t-ist.) }\end{array}$ & $\begin{array}{c}\boldsymbol{\beta}_{2} \\
(\mathrm{t} \text {-ist.) }\end{array}$ & $\overline{\boldsymbol{R}}^{2}$ & F-ist. & VIF \\
\hline 2005 & 210 & $\begin{array}{c}0,0052 \\
(0,0822)\end{array}$ & $\begin{array}{c}0,5286 \\
(6,0330)^{* * *}\end{array}$ & $\begin{array}{c}0,5619 \\
(5,9897)^{* * *}\end{array}$ & 0,5851 & $148,3808^{* * *}$ & 2,3380 \\
\hline 2006 & 203 & $\begin{array}{c}0,3299 \\
(2,4797)^{* *}\end{array}$ & $\begin{array}{c}0,5545 \\
(4,4705)^{* * *}\end{array}$ & $\begin{array}{c}0,5192 \\
(3,2084)^{* * *}\end{array}$ & 0,3676 & $59,6968 * * *$ & 2,3020 \\
\hline 2007 & 201 & $\begin{array}{c}0,1483 \\
(1,1282) \\
\end{array}$ & $\begin{array}{c}0,5228 \\
(3,2605)^{* * *}\end{array}$ & $\begin{array}{c}0,0247 \\
(0,1162) \\
\end{array}$ & 0,1073 & $13,0173^{* * *}$ & 2,3210 \\
\hline 2008 & 185 & $\begin{array}{c}0,3973 \\
(4,5186)^{* * *}\end{array}$ & $\begin{array}{c}0,4455 \\
(4,2869)^{* * *}\end{array}$ & $\begin{array}{c}0,3747 \\
(3,9148)^{* * *}\end{array}$ & 0,2384 & $29,7944 * * *$ & 1,2340 \\
\hline 2009 & 212 & $\begin{array}{c}0,1185 \\
(1,4988)\end{array}$ & $\begin{array}{c}0,2079 \\
(2,5828)^{* *}\end{array}$ & $\begin{array}{c}0,5466 \\
(3,2801)^{* * *}\end{array}$ & 0,1277 & $16,4423 * * *$ & 1,2910 \\
\hline 2010 & 203 & $\begin{array}{c}0,0827 \\
(1,1070) \\
\end{array}$ & $\begin{array}{c}0,8078 \\
(6,3108)^{* * *}\end{array}$ & $\begin{array}{c}-0,1328 \\
(-0,7632) \\
\end{array}$ & 0,2596 & $36,4129 * * *$ & 2,1860 \\
\hline 2011 & 264 & $\begin{array}{c}0,3495 \\
(3,1300)^{* * *}\end{array}$ & $\begin{array}{c}-0,2309 \\
(-3,1555)^{* * *}\end{array}$ & $\begin{array}{c}0,6859 \\
(9,9221)^{* * *}\end{array}$ & 0,2683 & $49,2275^{* * *}$ & 1,1070 \\
\hline \multicolumn{8}{|l|}{ Panel B } \\
\hline TÜM & 1525 & $\begin{array}{c}0,3164 \\
(6,3727)^{* * *}\end{array}$ & $\begin{array}{c}0,1340 \\
(3,8435)^{* * *}\end{array}$ & $\begin{array}{c}0,4854 \\
(10,8798)^{* * *}\end{array}$ & 0,1638 & $150,2523 * * *$ & 1,6240 \\
\hline SINAİ & 1162 & $\begin{array}{c}0,3119 \\
(5,1219) * * *\end{array}$ & $\begin{array}{c}0,0964 \\
(2,4064)^{* *}\end{array}$ & $\begin{array}{c}0,5249 \\
(10,3515)^{* * *}\end{array}$ & 0,1677 & $117,9827 * * *$ & 1,6380 \\
\hline HİZMET & 363 & $\begin{array}{c}0,2994 \\
(4,0676)^{* * *}\end{array}$ & $\begin{array}{c}0,3864 \\
(5,6072)^{* * *}\end{array}$ & $\begin{array}{c}0,1958 \\
(2,0169)^{* *}\end{array}$ & 0,1670 & $37,2817 * * *$ & 1,5280 \\
\hline
\end{tabular}

Not: Panel A, (t) yılını; N, gözlem sayısını temsil etmektedir. *,**,*** sirasıly $\% 10, \% 5$, \%1 düzeyinde istatistiksel olarak anlamlılığı ifade etmektedir. VIF $<10$ ise, açıklayıcı değişkenler arasında çoklu doğrusal bağlantı problemi yoktur.

Tablo 5 incelendiğinde, toplulaştırılmış verilerde ve sınai sektöründe FASB'ın önermesini doğrulayan sonuçlara ulaşıldığı söylenebilir. Cari dönem nakit akışları ve karlar birlikte, gelecek dönem nakit akışlarını yıllık ortalama \%28 düzeyinde açıklamaktadır. Toplulaştırılmış verilerde açıklama düzeyi \%16'ya düşerken, karların gelecek dönem nakit akışları ile arasındaki ilişkinin cari nakit akışlarının ilişskisinden yaklaşık dört kat fazla olduğu görülmüştür. Sektörel analizlerde ise, sınai sektöründe karların ilişki katsayısı nakit akışlarının ilişki katsayısından beş kat daha fazlayken, hizmet sektöründe tam aksine nakit akışlarının ilişki katsayısı, karların ilişki katsayısından iki kat daha fazladır. Dolayısıyla gelecek dönem nakit akışlarının tahmininde sınai sektöründe karlar, hizmet sektöründe ise, nakit akışları daha başarılı bulunmuştur.

\section{SONUÇ VE DEĞERLENDİRME}

Finansal raporlamanın amacı, kullanıc1lara kararlarını verirken faydalı olacak finansal bilgilerin sunulmasıdır. Kullanıcıların kararlarının isabetli olabilmesi, finansal raporlarda 
özetlenen muhasebe bilgilerinin kaliteli olmasına bağlıdır. $\mathrm{Bu}$ çalışmada, sermaye piyasalarında kullanılan muhasebe bilgilerinin kalitesinin ölçülmesi amaçlanmıştır.

Elde edilen bulgular değerlendirildiğinde, birinci kalite boyutu (değer ilişkisi) çerçevesinde bilanço ve gelir tablosundan elde edilen özet muhasebe kalemlerinin (defter değeri ve karların) hisse senetlerinin piyasa değerini önemli düzeyde açıkladığı ve toplulaştırılmış verilerde karların defter değerine göre daha belirleyici olduğu görülmüştür. Sonuçlar sektörel açıdan analiz edildiğinde, sınai sektöründe defter değerinin, hizmet sektöründe ise, karların daha önemli olduğu söylenebilir.

İkinci kalite boyutu (karların sürekliliği) bağlamında karların genel olarak sürekli ve tahmin edilebilir olduğu görülmüştür. Bununla birlikte 2008 ve 2009 yıllarına ait sonuçlar dikkat çekicidir. Söz konusu yıllarda karların sürekliliği ve tahmin edilebilirliği bozulmuştur. $\mathrm{Bu}$ durumun küresel finansal krizin yarattığı olumsuz etkilerden kaynaklanabileceği düşünülmektedir.

Son kalite boyutu (nakit akışlarının tahmin edilebilirliği) ile ilgili olarak gelecek dönem nakit akışlarının tahmin edilmesinde karların, nakit akışlarına göre daha iyi bir gösterge olduğu söylenebilir. Sektörel sonuçlar karşılaştırıldığında, sınai sektöründe karların, hizmet sektöründe ise nakit akışlarının daha başarılı olduğu görülmüştür.

Uygulama sonuçları bir bütün olarak değerlendirildiğinde, teorik beklentilere uygun ve birbiriyle tutarlı sonuçlara ulaşıldığı görülmektedir. Özetle, Borsa İstanbul'da 2005-2012 yılları arasında muhasebe bilgilerinin hisse senedi göstergeleriyle değer ilişkisinin bulunduğu, karların sürekli (kaliteli) olduğu, karın bileşenleri açısından nakit akışlarının tahakkuklara nispeten sürekli olduğu ve gelecek nakit akışlarının tahmin edilmesinde, karların nakit akışlarına göre daha iyi bir gösterge olduğu sonucuna varılmıştır. Buradan hareketle, çalışma dönemi, gözlem kümesi ve ele alınan kalite boyutları bağlamında, Borsa İstanbul'da sunulan muhasebe bilgilerinin genel olarak kaliteli olduğunu söylenebilir. Çalışmanın en önemli kısıtı, çalışma döneminin kısa olmasıdır. Çalışma döneminin daha uzun olduğu bir gözlem kümesi, sonuçların güvenilirliğini arttıracaktır.

\section{KAYNAKLAR}

Akerlof, George A. (1970), "The Market for "Lemons": Quality Uncertainty and the Market Mechanism", The Quarterly Journal of Economics, Vol.84, No.3, pp. 488-500.

Aktaş, Hüseyin (2009), Hisse Senetleri Piyasasında Muhasebe Bilgilerinin Önemi: İMKB'de Değer İlişkisi Analizi, Gazi Kitabevi, Ankara.

Aktaş, Rabia.- Karğın, Sibel (2012), "Predictive Ability of Earnings and Cash Flows: Evidence from Turkish Firms' Cash Flow Statements Prepared by IAS 7", Journal of Money, Investment and Banking, No.25, pp. 171-180. 
Amir, Eli. - Harris, Trevor S.- Venuti Elizabeth K. (1993), "A Comparison of the ValueRelevance of U.S. versus Non-U.S. GAAP Accounting Measures Using Form 20-F Reconciliations. Journal of Accounting Research", Vol.31, pp. 230-264.

Aras, Güler (2004), "Sermaye Piyasalarında Asimetrik Bilgi Etkisi ve Piyasaların İşleyişindeki Rolü", İktisat İşletme Finans, Cilt 19, Sayı 225, ss. 81-94.

Ball, Ray. - Brown, Philip (1968). "An Empirical Evaluation of Accounting Income Numbers", Journal of Accounting Research, Vol.6, No.2, pp. 159-178.

Barth, Mary E. - Beaver, William H. - Landsman, Wayne R. (2001), "The Relevance of the Value Relevance Literature for Financial Accounting Standard Setting: Another View", Journal of Accounting and Economics, No.31, pp. 71-104.

Bartov, Eli. - Goldberg, Stephen R. - Kim, Myung-Sun (2001), "The Valuation-relevance of Earnings and Cash Flows: An International Perspective", Journal of International Financial Management and Accounting, Vol.12, No.2, pp. 103-132.

Bilgic, F.Ayzer. - İbis, Cemal (2013), "Effects of New Financial Reporting Standards on Value Relevance - A Study about Turkish Stock Markets", International Journal of Economics and Finance, Vol.5, No.10, pp. 126-140.

Borsa İstanbul Resmi İnternet Sitesi, http://www.borsaistanbul.com/ (16.06.2013)

Call, Andrew Crafton (2007), The Implications of Cash Flow Forecasts for Investors' Pricing and Managers’ Reporting Earnings, University of Washington, PhD Dissertation.

Cheng, Agnes C.S. - Hollie, Dana (2005), "The Persistence of Cash Flow Components into Future Cash $\quad$ Flows", http://ssrn.com/abstract=541293 or http://dx.doi.org/10.2139/ssrn.541293 (02.04.2013).

Collins, Daniel W. - Maydew, Edward L. - Weiss, Ira S. (1997), "Changes in the Valuerelevance of Earnings and Book Values over the Past Forty Years", Journal of Accounting and Economics, No.24, pp. 39-67.

Çetinkaya, Şahin (2012), "Asimetrik Bilginin Piyasalara Etkileri ve Finansal Krizlerdeki Rolü", Sakarya İktisat Dergisi, Vol.1, No.2, ss. 60-82.

Dechow, Patricia. - Ge, Weili. - Schrand, Catherine (2010), "Understanding Earnings Quality: A Review of the Proxies, their Determinants and their Consequences", Journal of Accounting and Economics, No.50, pp. 344-401.

Dechow, Patricia M. (1994), "Accounting Earnings and Cash Flows as Measures of Firm Performance: The Role of Accounting Accruals", Journal of Accounting and Economics, No.18, pp. 3-42.

Dechow, Patricia M. - Schrand, Catherine M. (2004), Earnings Quality, Research Foundation of CFA Institute. USA. http://www.cfapubs.org/doi/pdf/10.2470/rf.v2004.n3.3927 (16.05.2013). 
Dechow, Patricia M. - Kothari, S.P., - Watts, Ross L. (1998), "The Relation Between Earnings and Cash Flows", Journal of Accounting and Economics, No.25, pp. 133168.

Dichev, Ilia D. - Graham, John R. - Harvey, Campbell R., - Rajgopal, Shiva (2013), "Earnings Quality: Evidence from the Field", Journal of Accounting and Economics, No.56, pp. 1-33.

Dung, Nguyen Viet (2010), "Value-Relevance of Financial Statement Information: A Flexible Application of Modern Theories to the Vietnamese Stock Market", DEPOCEN Working Paper Series No. 2010/02.

Elmas, Bekir (2012), "Sermaye Piyasalarında Etkinlik ve Sınırlı Arbitraj: İMKB'den Deliller", İMKB Dergisi, Y11 13, Say1 49, ss. 43-62.

Fama, Eugene F (1970), "Efficient Capital Markets: A Review of Theory and Empirical Work", The Journal of Finance, Vol.25, No.2, pp. 383-417.

Farshadfar, Shadi. - Monem, Reza (2013), "Further Evidence on the Usefulness of Direct Method Cash Flow Components for Forecasting Future Cash Flows", The International Journal of Accounting, No.48, pp. 111-133.

FASB (1978). Objectives of Financial Reporting by Business Enterprises, Concepts Statement No. 1. http://www.fasb.org/pdf/con1.pdf (02.04.2013).

FASB (2010). Conceptual Framework for Financial Reporting-Chapter 1, The Objective of General Purpose Financial Reporting, and Chapter 3, Qualitative Characteristics of Useful Financial Information (a replacement of FASB Concepts Statements No. 1 and $\begin{array}{lllll}\text { No. } & \text { 2), } & \text { Concepts } & \text { Statement }\end{array}$ http://www.fasb.org/jsp/FASB/Page/PreCodSectionPage\&cid=1176156317989 (02.04.2013).

FINNET (Financial Information News Network). https://www.finnet.com.tr/ (05.01.2014)

Filip, Andrei. - Raffournier, Bernard (2010), "The Value Relevance of Earnings in a Transition Economy: The Case of Romania", The International Journal of Accounting, No.45, pp. 77-103.

Finger, Catherine A. (1994), "The Ability of Earnings to Predict Future Earnings and Cash Flow", Journal of Accounting Research, Vol.32, No.2, pp. 210-223.

Francis, Jennifer. - Schipper, Katherine (1999), "Have Financial Statements Lost Their Relevance?", Journal of Accounting Research, Vol.37, No.2, pp. 319-352.

Gençoğlu, Ümit Gücenme. - Ertan, Yasemin (2012). "Muhasebe Kalitesini Etkileyen Faktörler ve Türkiye'deki Durum", Muhasebe ve Finansman Dergisi, Say1 53, ss. 1-24. Hellström, Katerina (2006), "The Value Relevance of Financial Accounting Information in a Transition Economy: The Case of the Czech Republic", European Accounting Review, Vol.15, No.3, pp. 325-349. 
Herrmann, Don. - Inoue, Tatsuo. - Thomas, Wayne B. (2000), "The Persistence and Forecast Accuracy of Earnings Components in the USA and Japan", Journal of International Financial Management and Accounting, Vol.11, No.1, pp. 48-70.

Hicks, J. (1939). Value and Capital. Oxford, University Press: UK'den aktaran Katherine Schipper and Linda Vincent, 2003, Earnings Quality. Accounting Horizons, No.17, pp. 97-110.

IASB (2010). Conceptual Framework for Financial Reporting 2010. http://www.ifrs.org/News/Press-Releases/Documents/ConceptualFW2010vb.pdf (02.04.2013).

İç, Süleyman. - Aygün, Mehmet (2009), "Kar ve Nakit akışlarının Bilgisel İçeriği ve Bilgisel İçeriğe Etki Eden Faktörler: Türk Sermaye Piyasası Üzerine Bir İnceleme", Hacettepe Üniversitesi İ.̇̇.B.F Dergisi, Cilt 27, No.2, ss. 105-126.

Kamu Gözetimi, Muhasebe ve Denetim Standartları Kurumu (2011). Finansal Raporlamaya İlişkin Kavramsal Çerçeve. TMS/TFRS 2013 Seti.

Kamu Gözetimi, Muhasebe ve Denetim Standartları Kurumu (2011). TMS-7 Nakit Akış Tabloları. TMS/TFRS 2013 Seti.

Kamuyu Aydınlatma Platformu Resmi İnternet Sitesi, http://www.kap.gov.tr/ (16.05.2013).

Karan, Mehmet Baha (2001), Yatırım Analizi ve Portföy Yönetimi. Gazi Kitabevi, Ankara.

Karğın, Sibel (2013). "The Impact of IFRS on the Value Relevance of Accounting Information: Evidence from Turkish Firms", International Journal of Economics and Finance, Vol.5, No.4, pp. 71-80.

Kim, Myungsun. - Kross, William (2005), "The Ability of Earnings to Predict Future Operating Cash Flows Has Been Increasing-Not Decreasing", Journal of Accounting Research, Vol.43, No.5, pp. 753-780.

Lopez, Jose E. Miranda. - Nichols Linda M. (2012), "The Use of Earnings and Cash Flows in Investment Decisions in the U.S. and Mexico: Experimental Evidence", Journal of International Accounting, Auditing and Taxation, No.21, pp. 198-208.

Müslümov, Alövsat. - Aras, Güler (2004). "Kredi Piyasalarında Asimetrik Bilgi ve Bankacılık Sistemi Üzerindeki Etkileri", İktisat, İşletme-Finans Dergisi, Say1 222, ss. 55-65.

Ohlson, James A. (1991). "The Theory of Value and Earnings, and an Introduction to the Ball-Brown Analysis", Contemporary Accounting Research, Vol.8, No.1, pp. 1-19.

Ohlson, James A. (1995), "Earnings, Book Values, and Dividends in Equity Valuation", Contemporary Accounting Research, Vol.11, No.2, pp. 661-687.

Okuyan, H. Aydın (2009), "Asimetrik Bilginin Türk Bankacılık Sektörü ve Kredi Piyasaları Üzerine Etkisi", EconAnadolu 2009, Anadolu International Conference in Economics, June 17-19, 2009, Eskişehir, Turkey. 
Özdamar, Kazım (2004), Paket Programlar ile İstatistiksel Veri Analizi-2 (Çok Değişkenli Analizler), Kaan Kitabevi, Eskişehir.

Özer, Gökhan (1996), "Muhasebe Karları ile Hisse Senedi Verimleri Arasındaki İlişkiler: İMKB'de Deneysel Bir Analiz", Sermaye Piyasası Kurulu Yayın No.31: Ankara.

Özer, Gökhan (2002). "Firma Değerlemesinde Muhasebe Karlarının Rolü: İMKB'de Deneysel Bir Araştırma", İktisat İşletme ve Finans, Y11 17, No. 201, ss. 112-122.

Özkan, Serdar. - Balsarı, Çağnur Kaytmaz (2010), "Impact of Financial Crises on the Value Relevance of Earnings and Book Value: 1994 and 2001 Crises in Turkey", İktisat İşletme ve Finans, Y11 25, No.288, pp. 81-95.

Özkan, Serdar. - Durukan, M. Banu. - Dalkılıç, Fatih (2005), "Approaches to Measuring Quality of Earnings and Discussion of the Applicability of these Approaches to Istanbul Stock Exchange (ISE) Companies", I. Uluslararası Muhasebe Denetimi Sempozyumu ve VII. Türkiye Muhasebe Denetimi Sempozyumu, 20-24 Nisan, Antalya.

Penman, Stephen H. - Zhang, Xiao-Jun (2002), "Accounting Conservatism, the Quality of Earnings, and Stock Returns", The Accounting Review, Vol.77, No.2, pp. 237-264.

Richardson, Scott A. - Sloan, Richard G. - Soliman, Mark T. - Tuna, İrem (2005). "Accrual Reliability, Earnings Persistence and Stock Prices", Journal of Accounting and Economics, No.39, pp. 437-485.

Schipper, Katherine. - Vincent, Linda (2003), "Earnings Quality", Accounting Horizons, No.17, pp. 97-110.

Sloan, Richard G. (1996), "Do Stock Prices Fully Reflect Information in Accruals and Cash Flows About Future Earnings?", The Accounting Review, Vol.71, No.3, pp. 289-315.

Suadiye, Gulhan (2012), "Value Relevance of Book Value and Earnings under the Local GAAP and IFRS: Evidence from Turkey", Ege Akademik Bakış, Cilt 12, No.3, pp. 301-310.

Türel, Ahmet (2009), "The Value Relevance of IFRS: The Case of Turkey", Economica, Vol.5, No.1, pp. 119-128.

Yel, Tülay (2012), "Kar Kalitesi ve Hisse Senedi Getirileri Arasındaki İlişskinin İMKB'de Test Edilmesi", Uluslararası Yönetim İktisat ve İşletme Dergisi, Cilt 8, Sayı 16, ss. 119-136. 
